Dicle University Journal of Engineering (DUJE)

web: http://dergipark.gov.tr/dumf

Araştırma Makalesi / Research Article

\title{
Suriyeli Göçmen ve Türk Vatandaşı Ailelerde, Evsel Atık ve Geri Dönüşüm Özelliklerinin Karşılaştırmalı Analizi
}

\section{Comparative Analysis of Domestic Waste and Recycling Properties in Syrian Immigrant and Turkish Citizen Families}

\author{
Hakkı Gülşen ${ }^{1}$, İbrahim Yenigün ${ }^{2 *}$ \\ ${ }^{1}$ Harran Üniversitesi, Çevre Mühendisliği Bölümü, Şanlıurfa, hgulsen@harran.edu.tr \\ ${ }^{2}$ Harran Üniversitesi, Mimarlık Bölümü, Şanlıurfa, ibrahimyenigun@hotmail.com
}

\begin{tabular}{|c|c|}
\hline MAKALE BİLGİLERİ & ÖZET \\
\hline Makale geçmişi: & $\begin{array}{l}\text { Günümüz dünyasının en büyük sıkıntılarından biri de göç olaylarıdır. } 2011 \text { yılında Suriye'de baş gösteren karışıklıklar } \\
\text { nedeniyle başlayan göç olayları ise II. Dünya Savaşı'ndan bugüne, dünyada yaşanan en büyük göç sorunu olarak kabul }\end{array}$ \\
\hline Geliş:24 Mart 2020 & edilmektedir. Yüzyılın dramatik olaylarından biri olarak ortaya çıkan bu göç olayından, en çok Türkiye ve de özellikle \\
\hline Düzeltme: 25 Nisan 2020 & Türkiye'nin Suriye'ye sınırı olan şehirleri etkilenmiștir. Bu etkileşim, kendini ekonomik, sosyal, güvenlik, toplumsal ve \\
\hline Kabul: 26 Nisan 2020 & daha birçok alanda negatif olarak göstermiştir. Yaşananlar, ülke gündemine, çözüme kavuşturulması gereken birbirinden \\
\hline Anahtar kelimeler: & $\begin{array}{l}\text { önemli sorunları taşımıştır. Problemler listesinin en önde gelenlerinden biri de artan göçmen nüfusuna bağlı her geçen gün } \\
\text { artış gösteren çevresel konularla ilgili problemlerdir. Birçok konuda kirletici yükünün artışına sebebiyet veren göçmen }\end{array}$ \\
\hline Göçmen, evsel atık, geri dönüşüm & $\begin{array}{l}\text { nüfus artışı, çözümlerin getirilmesi adına, konunun her yönden incelenmesi, araştırılması ve gelecek planlamaların } \\
\text { yapılması adına veri teminini zaruri kılmıştır. Bu düşünceden hareketle yapılan çalışmada, göçmen ailelerin evsel atık ve } \\
\text { geri dönüşüm konusundaki özelliklerini ortaya çıkarmak ve mevcut yerli ailelerinkiyle karşılaştırılmasına ait verilerin } \\
\text { oluşturulması hedeflenmiştir. Çalışma ile Suriye'den gelen göçmen ailelerin Türk ailelerin yaşam tarzlarıyla benzerlik } \\
\text { gösterdiği ve buna bağlı olarak da günlük davranış, beslenme ve sonucunda oluşan atık miktar ve özelliklerinin anlaml } \\
\text { farklılık göstermediği ortaya konmuştur. Elde edilen verilere bağlı olarak da, ülkemizin mevcut durumunu olduğu kadar } \\
\text { yarınlarını da büyük ölçüde ilgilendiren yorum ve önerilerde bulunulmuștur. }\end{array}$ \\
\hline
\end{tabular}

Doi: $10.24012 /$ dumf. 708636

\begin{tabular}{ll}
\hline ARTICLE INFO & $\begin{array}{l}\text { ABSTRACT } \\
\text { One of the biggest problems of today's world is migration events. The emigration events that started in 2011 due to the } \\
\text { upheavals in Syria were carried out by the II. Since World War II, it is regarded as the biggest migration problem in the } \\
\text { world. Century's dramatic events emerged as one of the events of this migration, the most affected city, especially Turkey } \\
\text { and Turkey's border with Syria. This interaction has shown itself to be negative in economic, social, security, social and } \\
\text { many other areas. The events brought to the agenda of the country important problems that need to be resolved. One of } \\
\text { the foremost issues in the list of problems is the increasing environmental problems associated with the increasing } \\
\text { Revised: } 25 \text { April } 2020 \\
\text { Accepted: } 26 \text { April } 2020\end{array}$ \\
\hline Keywords: & $\begin{array}{l}\text { immigrant population. The increase in the population of migrants, which caused an increase in the burden of pollutants } \\
\text { on many issues, made it necessary to provide data in order to bring about solutions, to examine, investigate and make } \\
\text { future plans in all aspects. In this study, it is aimed to reveal the characteristics of migrant families about household waste } \\
\text { and recycling and to create data for comparison with existing domestic families. The study revealed that immigrant } \\
\text { families coming from Syria show similarities with the Turkish families' lifestyles and accordingly, daily behavior, } \\
\text { nutrition and the amount and characteristics of waste generated as a result do not differ significantly. Depending on the } \\
\text { recycling }\end{array}$ \\
data obtained, comments and suggestions have been made, which concern the current situation of our country as well as \\
the future.
\end{tabular}

\footnotetext{
* Sorumlu yazar / Correspondence

İbrahim YENİGÜN

$\triangle$ ibrahimyenigun@hotmail.com
} 


\section{Giriș}

İnsanlık tarihi, çeşitli nedenlerden kaynaklı sayısız göç olaylarına tanıklık etmiştir. 20. Yüzyılda ortaya çıkan göç olayları ise en çok iki ülke arasındaki savaş ve iç karışıklıklardan dolayı gerçekleşmiştir. $\mathrm{Bu}$ tip zorunlu göçler, diğer nedenlerden kaynaklanan göç olaylarından farkl11ık göstermektedir [1]. Savaş ve benzeri sebeplerden kaynaklı yaşanan göçler, daha yoğun gerçekleşmekte, bağlı olarak etkilerini daha büyük ve uzun vadeli olarak yansıtmaktadır. Özellikle ekonomik, sosyolojik, güvenlik ve toplumsal boyutlarıyla yaşanan etkileri, hayati boyuttadır. Bu durum, göç ve göçmenler konusunu ülkelerin gündem maddelerinde öne çıkarmakta, ülkelerin sadece mevcut hallerini değil yarınlarını da oldukça yakından ilgilendirdiği için etkili ve köklü çözümlerin getirilmesini de zorunlu kılmaktadır.

Göç hareketleri sonrası birtakım sorunlar yaşayan göçmenler, sı ğındıkları devletlerde de önemli problemlerin öznesi konumunda olmaktadırlar [2]. Ev sahibi ülkelerde yaşanan problemlerin kriz boyutuna dönüştüğü hususlardan biri de çevresel problemlerdir. Hedef ülkelerde artan göçmen nüfusuna bağl1, çevresel problemler de artan bir ivmeyle kendini göstermektedir. Dolayısıyla, göçlerin çevresel boyutta yaşattıklarının yeni bir bakış açısıyla ve detaylica ele alınmasi hayati önem kazanmaktadır. İncelenmesi ve çeşitli önlemlerin alınmasını gerektirecek bu hususlardan biri de, yoğun göçmen nüfusuna bağlı atık tesislerine tahmin edilenden çok daha fazla yük binmesine ve tesislerdeki işletme problemlerine sebep olan evsel atıklardır [3]. Bununla birlikte, günümüzde çevre ve kaynakların korunması, verimlilik artışı ve kirlenmenin önlenmesi gibi başlıca faydalarından dolayı atık yönetim sistemlerinin ciddi olarak ele alındığı bilinen önemli bir gerçektir. $\mathrm{Bu}$ düşünceden hareketle yapılan çalışmada, göçmen ailelerin evsel atık ve geri dönüşüm konusundaki özellikleri, davranış modelleri ortaya çıkartılmış, mevcut yerli ailelerinkiyle karşılaştırılmış ve sonuç bilgileri sunulmuştur. Ayrıca, yerli ve Suriyeli ailelere ait geri dönüşüm atıklarının benzer ve farklılıkları ortaya konularak, konuyla ilgili yorumlar getirilmiştir.

\section{Türkiye ve Suriyeli Göçmenler}

XX. yüzyılın son yarısında göç olaylarının çokça yaşandığı dünyamızda, neredeyse tüm devletlerin göçten çeşitli oranlarda etkilendiği gözlenmektedir. Özellikle uluslararası göç hareketleri, çok sayıda ülkeyi eş zamanlı etkilemekte ve çözüme kavuşturulması gereken sorunlar olarak devletlerin gündemine taşımaktadır. Son elli yıllık süreç incelendiğinde, dünya genelinde iki yüz milyon civarında göçmen olduğu bilinmektedir. Yapılan tahminlere göre ise 2050 'de dünyadaki göçmen sayısının 405 milyona ulaşacağı beklenmektedir [4].

Türkiye, oldukça büyük öneme sahip konumuna bağlı, tarihi boyunca toplu göç olayları da dâhil olmak üzere büyük göç hareketlerinin yaşandığ 1 bir bölge olmuştur. Özellikle, 2010 yılında Suriye'de başlayan iç savaş sonrası, 2011 yılından itibaren Suriyeli mültecileri misafir eden Türkiye, Arap Baharı'ndan ciddi oranda etkilenmiştir. Sayıları beş milyonu aşan insan grupları, başta Türkiye olmak üzere Lübnan, Ürdün, Irak gibi ülkelere göç etmiştir.

Suriyeli mültecilerin Türkiye'de büyük ölçüde yaşadığı şehirlerin dağılımı ele alındığında, Suriye'ye komşu olmalarından kaynaklı Güneydoğu kentlerinin ön plana çıktıkları izlenmektedir (Şekil-1). Göç idaresinin 2019 yılı istatistik verilerine göre, Suriyeli göçmenlerin en çok bulunduğu ilk üç kent sırasıyla İstanbul, Gaziantep ve Şanlıurfa olmuştur. Bu gerekçeyle de çalışma alanı olarak, 430537 Suriyeli göçmen barındıran ve buna bağlı sıralamada üçüncü il olan Şanlıurfa ili seçilmiştir.

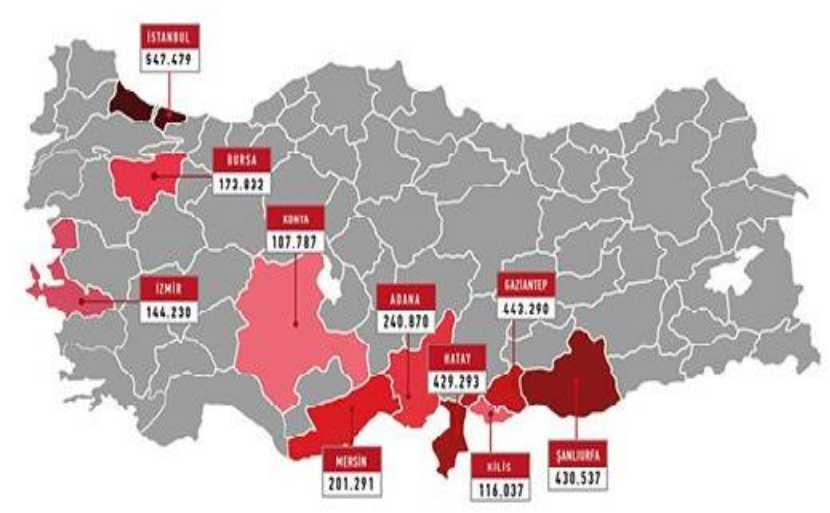

Şekil 1: Illlere göre Suriyeli sı̆̆ınmacı sayıları [5]. 


\section{Evsel Atık ve Geri Dönüşüm}

Atıklar, insan aktiviteleri sonucu oluşan, kullanılamaz hale gelmiş ve istenmeyen maddeler olarak tanımlanmaktadır. İnsanlığın ilk varoluşuyla başlayan atık oluşumu, ilk dönemlerde sorun oluşturmazken, artan nüfus ve azalan araziye bağlı büyük problemler arasında kendine yer bulmaktadır [6].

Günümüz dünyasında kentleşme, nüfus artış1, sanayileşme, konforlu yaşam ve bağlı olarak değişen tüketim anlayışı ile ortaya çıkan atıklar, insanoğlunun geleceğini, sağlığını ve çevresini olumsuz olarak etkilemektedir [7]. İnsanoğlunun aşırı ve artan tüketimi, doğanın kendini yenileme kapasitesini aşmakta, çevre problemlerini çözülmesi zor boyutlara taşımakta ve bu yenileme gücünü ortadan kaldırmaktadır [8]. Dolayısıyla, atıkların ve zararlı etkilerinin minimum seviyeye indirilmesi, kaynakların etkin ve yeniden kullanımının sağlanması, gelecek nesillere ulaştırılması, devletlerin zorunlu ve öncelikli halletmesi gereken meseleleri olarak ortaya çıkmaktadır [9]. Bu bağlamda da çözüm ve sürdürülebilirlik stratejileri olarak azaltma (reduction), yeniden kullanım (reuse) ve geri dönüşüm (recycling) uygulamalarından oluşan 3R stratejisi etkin metot olarak benimsenmektedir. Azaltma uygulamasi; malzeme kullanımını, sanayi atıklarını daha az paketleme yapmak, ürünleri koruyarak ömürlerinin uzatılmasını amaçlamaktadır. Yeniden kullanım; ürünün aynı döngü içinde tekrar kullanımının sağlanmasıdır. Geri dönüşüm ise ürün atı malzemelerinden tekrar üretilmesinin sağlanmasıdır. Atık kağıtların yeniden kağıda dönüştürülmesi, atık cam şişelerin tekrar cam haline dönüştürülmesi uygulamaları başlıca örneklerindendir [10]. Bu uygulamalardan geri dönüşüm yöntemi, gerçekleşmesindeki önemli görevi özellikle tüketici ayağına yüklemekte, bu sebepten dolayı çalışma konumuzun başlığını teşkil etmektedir.

Çalışma konusuna esas teşkil eden Suriyeli göçmen nüfusun oluşturduğu atı ise Türkiye'deki atık tesislerine öngörülemeyen büyük bir baskı oluşturmuş, başta evsel atıklar olmak üzere tüm atıkları içine alan entegre yaklaşımları gerekli kılmıştır.

\section{Materyal ve Metot}

Şanlıurfa'da yaklaşık yarım milyon Suriyeli vatandaş yaşamakta olup bununla beraber Şanlıurfa şehrinin toplam nüfusu iki milyonu aşmaktadır. $\mathrm{Bu}$ veriler 1şı̆̆ında çalışma alanı olarak Şanlıurfa seçilmiştir. Artan nüfusla beraber toplam çöp miktarı, toplama-taşıma maliyeti artmış, düzenli depolama alan ihtiyacı, kalifiye eleman ve işçi sayısının artmasının yanında makine ve ekipman ihtiyacı da artmıştır. $\mathrm{Bu}$ ihtiyaçları karşılamak adına çevre bilinci, çevre sağlığı, insan refahı, sürdürülebilirlik konuları esas alınarak çalışmanın yapılması kararlaştırılmıştır. Suriyeli vatandaşların evsel çöpleri ile Türk vatandaşlarının evsel çöpleri içindeki geri dönüşüm atıklarının miktar, tür ve oranlarının belirlenmesi amaçlanmıştır.

Tespit edilen tüm bu gereksinimler doğrultusunda; Şanlıurfa'nın farklı nüfus, bölge ve gelir seviyelerinde altı Suriye uyruklu aile ve altı yerli aile belirlenmiştir. Toplam 12 aileye öncelikle, evsel atık ve geri dönüşüm hakkında bilgi ve bilinçlendirmeler yapılmıştır. Her eve farklı renklerde (siyah-mavi) poşetler ve dijital tartı aletleri verilmiştir. Siyah poşetlere günlük organik-inorganik atıkların atılması ve mavi poşetlere ise geri dönüşüm niteliğindeki atıkların yerleştirilmesi bilgisi verilmiştir. Bu sınıflamaya göre yapılan toplama işlemlerinin ardından, her gün saat 21.00 'da verilen dijital el tartılarıyla poşetlerin tartılması ve kırk beş gün boyunca verilerin yazılı olarak kayıt altına alınması sağlanmıştır.

\section{Araştırma Bulguları}

Çalışma, 45 günlük sürede tamamlanmıştır. Türkiye vatandaşı yerli aileler TR kısaltma ibaresi ve Suriye uyruklu göçmen aileler ise SR kısaltma ibaresi ile tanımlanmıştır. 6 TR ve 6 SR haneden oluşan toplam 12 lokasyon belirlenmiştir. TR hanelerinde 34, SR hanelerinde ise 35 kişi olup çalışmade yer verilen toplam nüfus 69 kişiden oluşmaktadır. Ortalama hane başı nüfus 8 kişidir. Çalışma sonunda elde edilen veriler, çeşitli parametreler doğrultusunda aşağıdaki grafiklerde gösterilmektedir. 


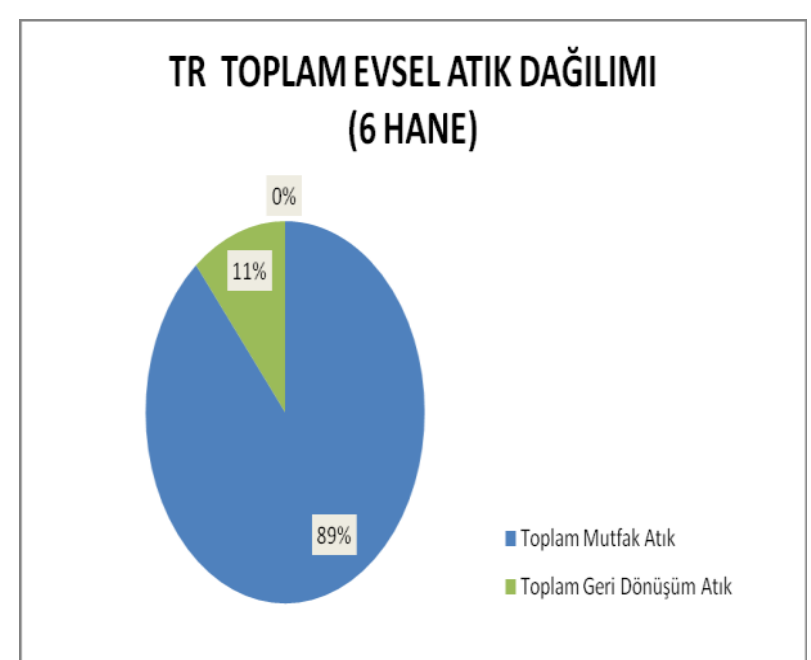

Grafik 1: Yerli ailelerin 45 günlük toplam evsel atık dağılımı (\%)

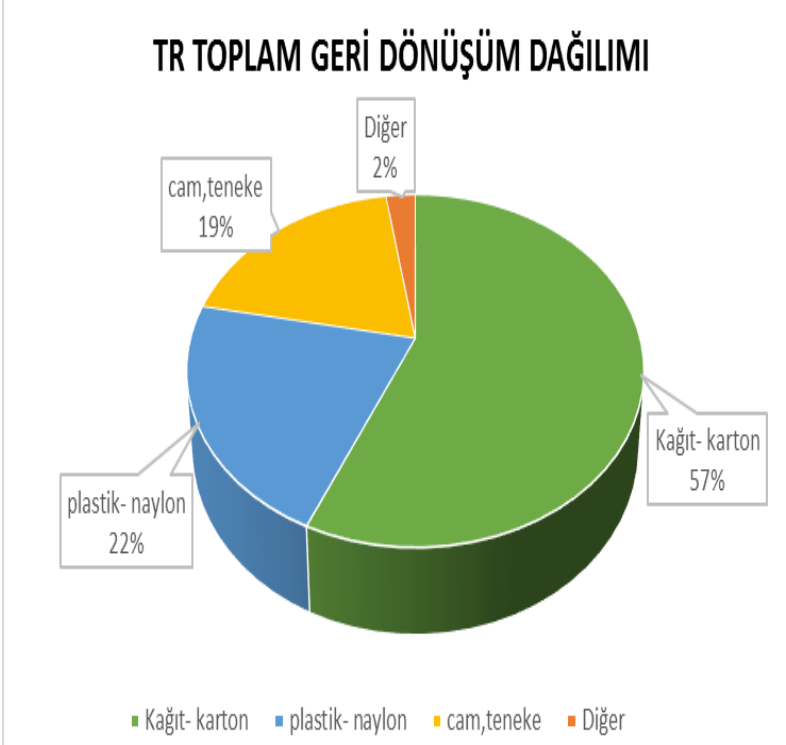

Grafik 2: Yerli ailelerin 45 günlük toplam geri dönüşüm nitelikli atık dağılımı (\%)

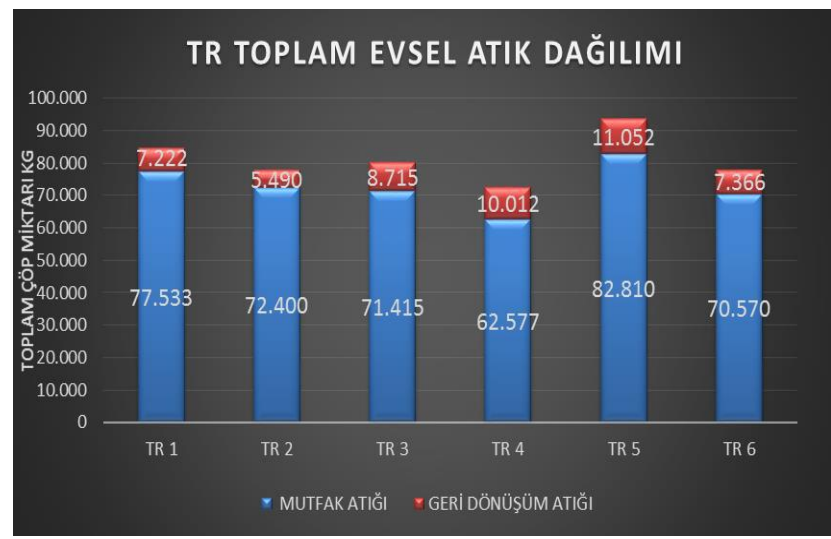

Grafik 3: Yerli ailelerin 45 günlük toplam evsel atık dăğlımı (kg)

\section{SR TOPLAMEVSEL ATIK DAĞILIMI (6 HANE)}

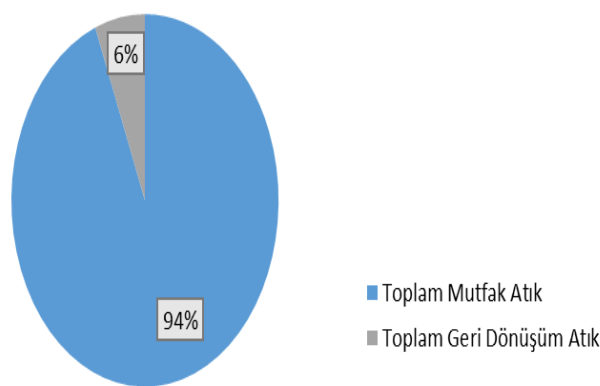

Grafik 4: Suriyeli göçmen ailelerin 45 günlük toplam evsel atık dağılımı (\%)

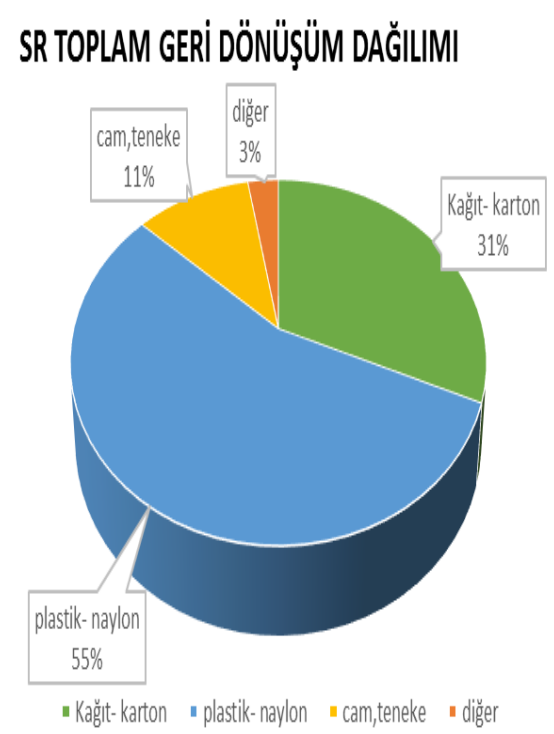

Grafik 5: Suriyeli göçmen ailelerin 45 günlük toplam geri dönüşüm nitelikli atık dağılımı (\%)

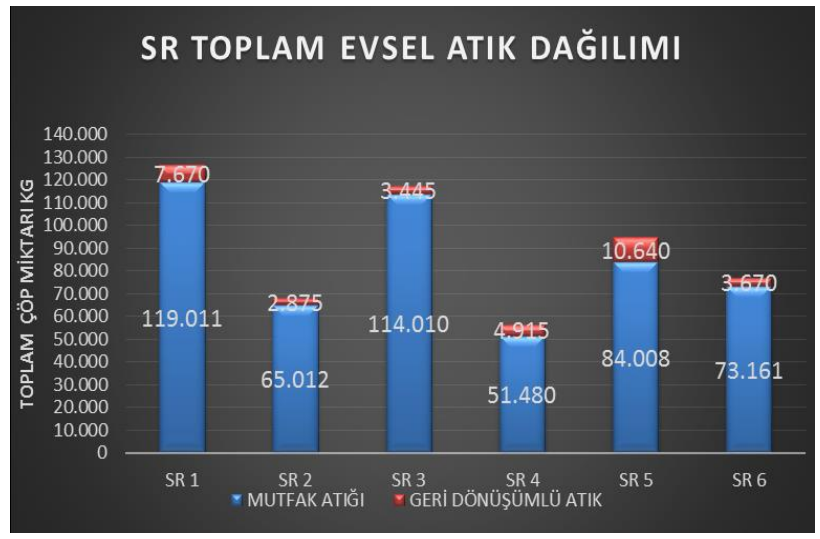

Grafik 6: Suriyeli göçmen ailelerin 45 günlük toplam evsel atık dağılımı ( $\mathrm{kg}$ ) 


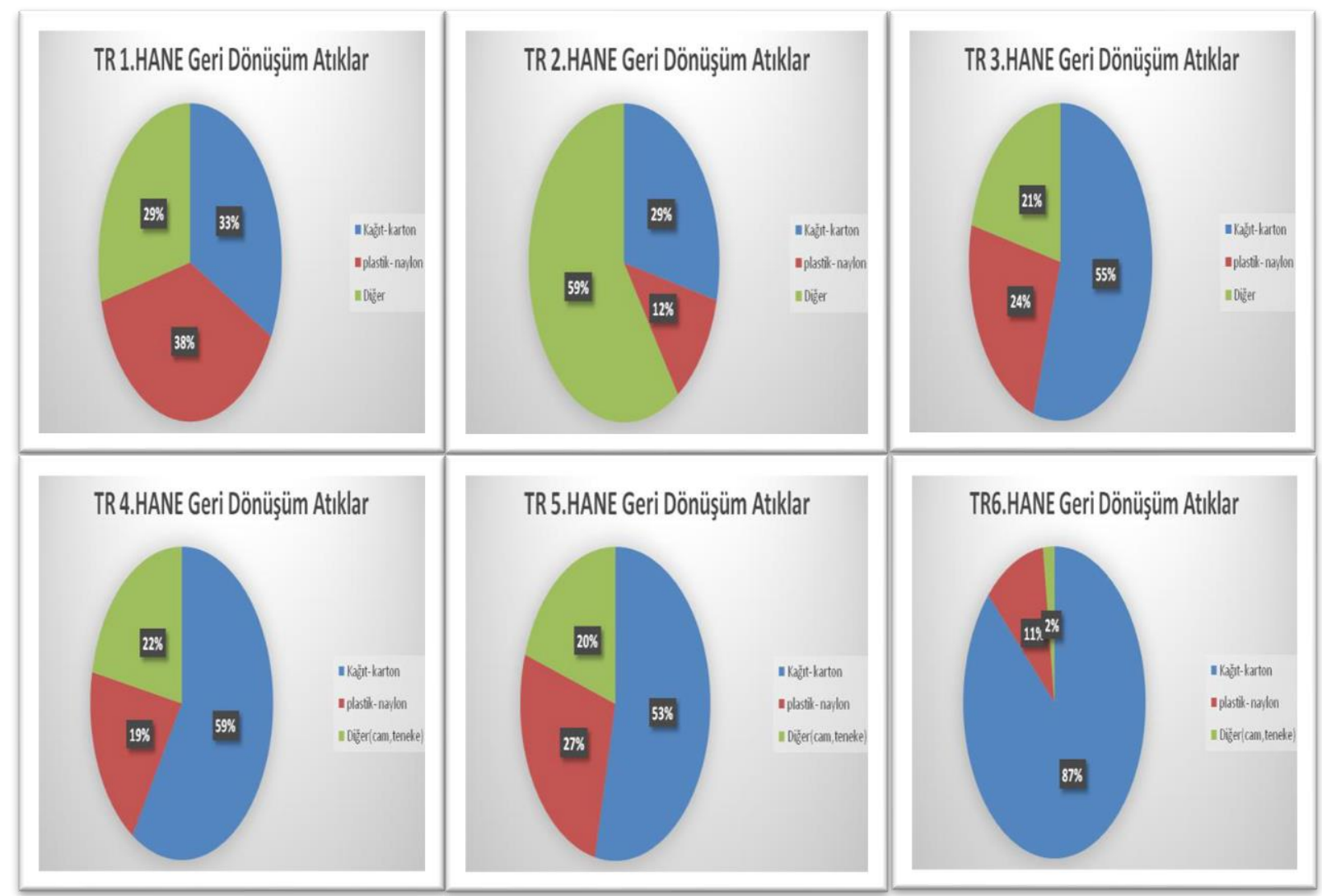

Grafik 7: Yerli ailelerin ayrl ayrl toplam evsel atık dağılımı (\%)

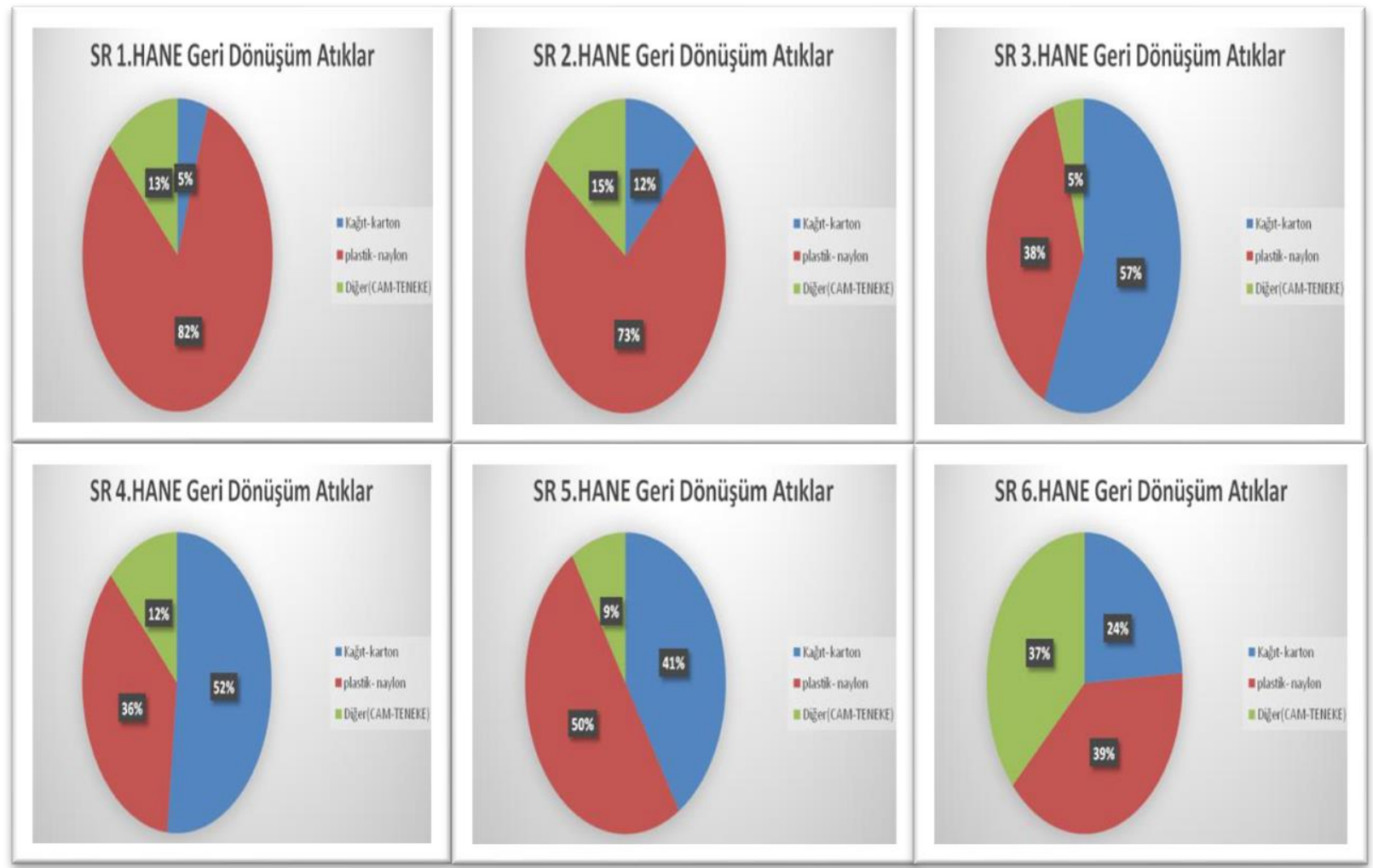

Grafik 8: Suriyeli göçmen ailelerin ayr ayr toplam evsel atık dağılımı (\%) 


\section{Sonuçlar ve Tartışma}

Genel anlamda, Suriyeli göçmen ailelerin geldikleri ülke olan Suriye'nin Türkiye'ye komşu ülke olmasına bağlı olarak yaşam tarzları benzer özellik göstermektedir. Buna bağlı olarak da günlük davranıș, beslenme ve sonucunda oluşan atık miktar ve özelliklerinin anlamlı farkl1lık göstermediği söylenebilmektedir. Çalışmadan elde edilen verilere, ayrı ayrı ve toplam olarak aşağıdaki tablo 1 'de yer verilmektedir.

Tablo 1: Suriyeli göçmen ve yerli ailelerin ayrt ayrı ve toplam evsel atık dăğlımı ( $\mathrm{kg}$ )

\begin{tabular}{|l|l|l|l|l|}
\hline & $\begin{array}{l}\text { TR } \\
\text { Mutfak } \\
\text { Atığ } \\
\text { (kg) }\end{array}$ & $\begin{array}{l}\text { SR } \\
\text { Mutfak } \\
\text { Atığı } \\
\text { (kg) }\end{array}$ & $\begin{array}{l}\text { TR } \\
\text { Geri } \\
\text { Dön. } \\
\text { Atık } \\
\text { (kg) }\end{array}$ & $\begin{array}{l}\text { SR } \\
\text { Geri } \\
\text { Dön. } \\
\text { Attk } \\
\text { (kg) }\end{array}$ \\
\hline 1. Hane & 77.533 & 119.011 & 7.22 & 7.670 \\
\hline 2. Hane & 72.400 & 65.012 & 5.490 & 2.875 \\
\hline 3. Hane & 71.415 & 114.010 & 8.715 & 3.445 \\
\hline 4. Hane & 62.577 & 51.480 & 10.012 & 4.915 \\
\hline 5. Hane & 82.810 & 84.008 & 11.052 & 10.640 \\
\hline 6. Hane & 70.570 & 73.161 & 7.366 & 3.670 \\
\hline $\begin{array}{l}\text { TOPLAM } \\
\text { (kg) }\end{array}$ & $\mathbf{4 3 7 . 3 0 5}$ & $\mathbf{5 0 6 . 6 8 2}$ & $\mathbf{4 9 . 8 5 5}$ & $\mathbf{3 3 . 2 1 5}$ \\
\hline
\end{tabular}

Bununla birlikte yapılan çalışmanın detaylı analizi yapıldığında şu sonuçlardan bahsetmek mümkündür;

Hane başı birim çöp miktarı hesaplandığında TR aileler için $1.82 \mathrm{~kg} /$ hane.gün ve SR aileler için 2 $\mathrm{kg} /$ hane.gün olarak bulunmuştur. Kişi başı birim çöp miktarları ise TR için $320 \mathrm{~g} /$ kişi.gün ve SR için $342 \mathrm{~g} /$ kişi.gün olarak hesaplanmıştır.

TR ailelerin toplam atık miktarı, SR ailelerinin toplam miktarından yaklaşık \%20 daha fazladır. Bu durum SR ailelerin barındıkları evlerde, çok fazla eşya bulundurmadıkları sadece temel ihtiyaçlarını karşılama yoluna gittiklerini ve buna bağlı daha az atık oluşturdukları varsayımını düşündürmektedir.
Geri dönüşüm niteliğindeki atıklar ele alındığında, yine TR ailelerin daha fazla geri dönüşüm nitelikli atı oluşturduğu görülmektedir. $\mathrm{Bu}$ parametre daha detaylı incelendiğinde; TR ailelerde kağıt türevi atıkların daha fazla, SR ailelerde ise plastik türevi atıkların daha fazla yer aldığı görülmektedir. $\mathrm{Bu}$ durum, SR ailelerin göçmen olarak yaşadıkları evlerde günlük yaşam, yeme, içme ve kullanım malzemelerini tek kullanımlık malzemelerden tercih ettiklerini göstermektedir.

Türkiye, Suriyeli göçmenlere "açık kap1 politikası" uygulanmasını ve hayati ihtiyaçlarının temin edilmesini, insani sorumluluk olarak değerlendirmiş ve bu anlayışa dayalı yürütülen bir süreç takip etmiştir. Bundan dolayı da Suriyeli göçmen sayısı ciddi rakamlara ulaşmıştır. Türkiye'ye yönelik artan Suriye göçü, ülkenin ekonomisini, sosyal yaşamını, güvenliğini, demografik yapısını, kamu düzenini ve benzeri daha pek çok parametreye bağlı olarak da geleceğini yüksek düzeyde etkilemektedir. Ortaya çıkan durum, etkili bir göç yönetimi ihtiyacını gerekli ve hatta hayati kılmaktadır. Çevresel konular başta olmak üzere, tüm konuların ayrıntılarıyla ele alınması ve geleceğe dönük her türlü yapılanma ve planlamaların gerçekleştirilmesi gerekmektedir. İlk zamanlarda kısa vadeli kalacakları düşünülen Suriyeli mültecilerin, uzun zaman daha Türkiye gündemini yakından ve ilk sıralardan meşgul edeceği öngörüsünden hareketle konunun, bütüncül bir anlayışıyla ele alınması gerekmektedir. Dolayısıyla konumuz olan atık oranları açısından da bakıldığında; her tür atık tesisinin bu bilgiler 1şığındaki kapasitelerinin planlanması, Suriyeli mültecilerin başta toplu yaşadıkları bölgeler olmak üzere tüm yaşam alanlarında geri dönüşüm hakkında bilinçlendirilmeleri ve geri kazanımın sağlanması önem arz etmektedir. $\mathrm{Bu}$ şekilde aktive edilen göçmen ailelerin geri dönüşüm sayesinde ekonomiye ve doğal kaynakların korunmasına belirli oranlarda katk1 vermeleri sağlanmış olup, ülke üzerine yaşatılan yükün hafifletilmesi öngörülmektedir. 


\section{Kaynaklar}

[1] Tunç, A.Ş. (2015). Mülteci Davranışı ve Toplumsal Etkileri: Türkiye'deki Suriyelilere İlişkin Bir Değerlendirme, TESAM Akademi Dergisi, 2(2).

[2] Efe, İ. (2015). Türk Basınında Suriyeli Sığınmacılar, SETA Rapor.

[3] Yenigün, İ. ve Uyanık, S. (2018). Güneydoğu Anadolu Bölgesindeki Çevresel Altyapılar Üzerine Suriye Kaynaklı Göçlerin Etkileri, ISEM, Bosnia and Herzegovina, 27-29 June.

[4] 2016 Türkiye Göç Raporu. (2017). T.C. İçişleri Bakanlığı Göç İdaresi Genel Müdürlüğü Yayınları, Yayın No:40, Ankara.

[5] URL-1 BİANET, Bağımsız İletişim Ağı sitesi, http://bianet.org/bianet/insan-haklari/210836-gocidaresi-genel-mudurlugu-verilerine-gore-turkiyedeki-suriyeliler (26.04.2020).

[6] Beyhan, M. (1997). Isparta Evsel ve Ticari Katı Atıklarından Geri Kazanılabilir Maddelerin Potansiyelinin Araştırılması, Yüksek Lisans Tezi, Yıldız Teknik Üniversitesi Fen Bilimleri Enstitüsü, İstanbul.
[7] Palabıyık, H. ve Altunbaş, D. (2004). "Kentsel Katı Atıklar ve Yönetimi”, Editörler: M.C. Marin ve U. Yıldırım, Çevre Sorunlarına Çağdaş Yaklaşımlar Ekolojik, Ekonomik, Politik ve Yönetsel Perspektifler, Beta yayınları, İstanbul, s.13-30.

[8] Kızılboğa, R ve Batal, S. (2012). "Türkiye'de Çevre Sorunlarının Çözümünde Yerel Yönetimlerin Rolü ve Önemi”. Mustafa Kemal Üniversitesi Sosyal Bilimler Enstitüsü Dergisi, Cilt:9, Sayı:20, s.191-212.

[9] Mazurkiewicz, P. (2005). Corporate Environmental Responsibility: Is a Common. CSR Framework Possible? World Bank Discussion Paper, http://siteresources.worldbank.org/EXTDEVCOMM ENG/Resources/csrframework.pdf (06.08.2019).

[10] Umut, M.Ö., Topuz, Y.V., Velioğlu, M.N. (2015). Çöpten Geri Dönüşüme Giden Yolda Sürdürülebilir Tüketiciler, CBÜ Sosyal Bilimler Dergisi, Cilt:13, Sayı:2, Haziran. 